\section{BRITISH IRON AND STEEL RESEARCH ASSOCIATION}

$\mathrm{T}$ HE manifold demands made by a live industry on its research association are well illustrated by some of the current activities of the British Iron and Steel Research Association. Co-operative research lends itself readily to organised investigation into the background problems of industrial processes. Some. times these are indicated by the failure of an unproved technique; sometimes by new demands on the part of the user which call for extension of knowledge and technique on the part of the supplying industry; but most often the process is dictated by the natural desire of the industry concerned to improve its processes, qualities and general economy.

An example of investigations stimulated by the failure of a technique insufficiently understood is the work which has been done on brittle fracture in mild steel plates. The welding in certain ships made in foreign countries during the War failed, and representatives of all British organisations interestedgovernmental and Service departments, other research associations, the universities, Lloyd's and numerous industrial laboratories-carried out various investigations culminating in a conference in October 1945. As a result of intensive discussion under the chairmanship of Dr. (now Sir Andrew) McCance, who is chairman of the council of the British Iron and Steel Research Association, the lines of research necessary for ascertaining the cause and cure of the phenomenon of brittle fracture were indicated.

Subsequent researches at the works of Colvilles Ltd., and at the University of Cambridge, established that brittle fracture was related to manganese content, plate thickness and the rate of cooling, the effect of the first factor being by far the greatest. Further work at Colvilles on small, closely controlled casts of steel made by the high-frequency process has now established that for a given tensile strength an increase in the manganese-carbon ratio of mild steel has the desired effect of lowering the temperature range below which one must go before brittle fracture may take place. This effect is related to the fact that the increased ratio also tends to give a fine-grain steel. The latest work on this subject is able to conclude with a practical recommendation that for shipbuilding steels the manganese-carbon ratio should not be less than $3 \cdot 0$.

The results to date of this extensive series of experiments have been distributed to the members of the Association and participants in the original conference, and are shortly to be made available to a wider public through the technical press.

Another project also bears on embrittlement, but in this case at high temperatures. The brittle constituent (sigma phase) of the iron - chromium and the iron-chromium-nickel systems is being studied at the National Physical Laboratory for the Association, as the appearance of this constituent during service at elevated temperatures can cause serious embrittlement in certain commercial alloys. Limits in composition to avoid the appearance of the sigma phase are now being defined for pure ternary alloys, and eventually the effect of other elements upon the systems will be investigated. A related and rather more extensive research deals with the influence of alloying elements on the properties of ferrite.

These latter projects may be taken as examples of investigations with the object of meeting new demands, in this case made by the designers of gas turbines and other high-duty engines. The successes met with by the works laboratories, working in com. petition, are well $\mathrm{kno} \mathrm{n}$, and may be said to be approaching their limils within the bounds of the available 'background' 1 nowledge. It is the natural task of the research asso iation to organise the pooling of information to th e necessary extent, and to widen our background $\mathrm{kr}$ owledge, thus enabling the industrial laboratories $t$, proceed once more in healthy rivalry. This is a continuing process, which an alert industry will dema ad of its research associa. tion without intermission.

The great bulk of the wor : of the British Iron and Steel Research Association, l owever, originates from the discussions of the voluntar ' panels and committees which supervise and canal ze the Association's activities. These committees \& re widely drawn from the iron and steel industry, the universities of Great Britain, Government researcl laboratories, steel users, etc. They are kept small, the total membership numbering about 450 for nearl' sixty committees. The Association's work is organi sed in six divisions, corresponding to the main divisiuns in the industry, each being controlled on a largely decentralized basis by a panel. There are also three, so to speak, 'horizontal' departments (physics, chemistry and engineering) which carry out more fundamental work and work common to a number of divisions, and incidentally play a useful part in maintaining liaison between the six divisions.

Some three hundred projects are in hand, covering the industry's production cycle from the blast furnace and its raw materials to the rolling mill, draw-bench and final application. These projects range from the severely practical to the 'purely' theoretical.

The modern blast furnace is highly efficient from a thermal point of view. Irnprovement is sought, however, in output, smooth working, high-grade production, requirements of special coke and in general operational economy. A considerable volume of work goes on in attempts to determine the best conditions and proportions of the constituents of the burden, the best methods of distribution and the extent of heat and gas penetration into various types and sizes of ore. Consideration is also being given to the use of gas turbines for blowing. The Association has an experimental blast furnace with a $1 \mathrm{ft} .9 \mathrm{in}$. hearth at Stoke-on-Trent where much of this work is carried out. This 'baby' is believed to be the smallest working blast furnace in existence.

At Stoke-on-Trent the Association has in addition a model open-hearth furnace, which for the last two years has afforded information of great importance on the design and operation of such furnaces. Also at the steel-making stage the factors affecting sulphur removal are being studied both in the plant and in the laboratory. Most of the latter work is done at the universities. The subjects of instrumentation and heat measurement receive their share of attention, and the new problems raised in the extensive programme of converting open-hearth furnaces to oil firing lend particular importance to these investigations. The Physics Department has constructed a black. body furnace with a 3-in. aperture for calibrating pyrometers up to $1,700^{\circ} \mathrm{C}$, and is also investigating problems in connexion with quick immersion thermocouples.

It is part of the task of the Chemistry Department to work in close collaboration with the British Refractories Research Association, and one of the 
big problems in this field is at present the development of the all-basic open-hearth furnace. This should have many advantages over the normal type with a silica roof, and its higher operating temperature should result in increased output.

In the field of steel castings, a thorough investigation is being made into foundry moulding materials and the fundamental mechanism whereby they are bonded together. The allied problems of hot tearing and the rate and direction of heat abstraction on solidification are being examined, as also are methods of controlling the melting process by spec. troscopic inspection of the flame of Tropenas converters during steel-melting.

Work going forward nearer the finishing end of the industry includes research on coating, rolling and drawing. At the Association's new laboratories in South Wales (see Nature, July 19, p. 100), work goes on concerned with the distribution, thickness and porosity of tin, zine and non-metallic coatings, and with further projects on the geometrical character. istics of metal surfaces.

In the investigations into drawing problems, the Physics Department has assisted in devising an instrument for measuring the tension in wire as it is drawn, the variations in oscillation under varying $t$ nsions being used for this purpose. Theoretical and practical work on plastic deformation in rolling goes forward at the Universities of Cambridge and Sheffield.

'The engineering problems that face the iron and steel industry are sometimes insufficiently regarded as being suitable objects of scientific approach. Here the Association's Plant Engineering Division has a wide field, and has done much useful work in organising conferences and other means of exchanging knowledge - a function of immediate importance in the industry's modernization plans. This Division also methodically studies steel-works transport, design and operation problems, and is responsible for a wide range of research on fuel problems.

This very brief summary suffices to show the immensely wide field an industrial research association has to cover. The work ranges from the most 'purely' theoretical study of the thermodynamic and chemical aspects of the steel-making process, to the most severely practical investigation into engineering problems. All this is comprehended in the mutual aim of science and industry to ensure that the methods and discoveries of the one shall be with the least delay at the service of the other.

\section{BOTANY OF THE WILD AND CULTIVATED RICES}

\author{
By DR. D. CHATTERJEE
}

The Herbarium, Royal Botanic Gardens, Kew

$\mathrm{A}$

LTHOUGH much work has been done on the widely cultivated species of rice (Oryza sativa Linn.) for its improvement as an agricultural crop, it must be admitted that our knowledge of its morphology and taxonomy and its relationship to other wild species of the genus is comparatively meagre. The term "wild rice' as employed here is used to indicate all other species which conform by their technical characters to the generic definition of Oryza, and which grow spontaneously in a wild state. The two cultivated species are the well-known Oryza sativa Linn. and the less known Oryza glaberrima
Steud. (cultivated in west tropical Africa). In tropical countries where these species are extensively culti vated, it is unfortunate that a comprehensive accoun. of the rice plant with a proper interpretation of ai the structures, its evolution and domestication by man is not generally given in text-books on botany and tropical agriculture. This omission makes its study uninteresting and often vague. The aim this note is to put together some of these muchneeded data with a suitable list for further reference.

\section{Domestication of 'Wild Rice' by Man}

The history of cultivated rice goes so far back into the distant past that it could be associated with the early history of man. It has been said that man has passed through three successive stages of civilization. that is, the hunting, pastoral, and agricultural. In the early stage men hunted in packs the wild animals of the grassland. The women also hunted with the men and equally shared the products of the chase. The cares of maternity and increased attachment to their homes often made it necessary for the women to drop out from the band for a time. Gradually women found it necessary to supplement their diet with nuts, berries and grains of grasses at times when the food supplies brought by their men-folk ran out. Homes were established near the seashore and banks of lakes and rivers. Fishes and molluscs were also gathered from these sources to supplement the food. Domestication of cattle began at this stage of pastoral life. The idea of growing grains of wild grasses by actual cultivation of land came later, and the exact circumstances are not known but are subject to various speculations.

Recent discoveries in India at Mohenjo-daro in Sind and at Harappa in the Punjab have shown that civilization entered the country as early as 3000 2500 B.c. It appears that the people who came to the Indus Valley at that time from the west had a knowledge of wheat cultivation and they readily adopted the wild rice which they found in that part of India. There is also reason for believing that the people of Mohenjo-daro had trade relations with the Sumerian cities of Mesopotamia, and both wheat and rice might have constituted the articles for trade. Between $400-300$ B.c. rice was cultivated beyond the western limits of India and later it was grown in Babylonia, Bacterina and lower Syria. During the early period of the Christian era cultivation was started in Persia and Egypt. In China and Indo-China. rice was in cultivation for a long time and no definite account is available how these countries received the art of rice cultivation from the Indus Valley. A possible suggestion is by way of the Hindu Kush, Tibet and Mongolia. The cultivation has spread to Malaysia, Africa and America in recent years. Knowledge of rice cultivation came to south-eastern Europe through the Arabs, who also introduced its cultivation in Spain after their conquest of that country.

The wild rice of India, which may be regarded as the ancestor of the cultivated rice, is found throughout India, Burma and Malaysia. It resembles the ordinary cultivated rice very much but has deciduous spikelets, $3-10 \mathrm{~cm}$. long awns, and a dark red spot between the apex of the lemma and the awn. Having taken this plant into domestication, early man, consciously or unconsciously, effected a general trend of improvement by selecting those plants which possessed certain desirable and stable characteristics. These might have been: (1) tufted growth and pro- 